\title{
Prognostic Value of De-Ritis Ratio in Adolescents and Young Adult Patients with Breast Cancer
}

\section{Adölesan ve Genç Yetişkin Meme Kanserli Hastalarda De-Ritis Oranının Prognostik Değeri}

\author{
Utku Oflazoglu' $^{1}$, Yakup iriagac ${ }^{2}$, Yuksel Kucukzeybek ${ }^{1}$, Umut Varol $^{1}$, Tarik Salman ${ }^{1}$, Halil \\ Taskaynatan $^{1}$, Yasar Yildiz ${ }^{1}$, Ahmet Alacacioglu ${ }^{1}$
}

\begin{abstract}
${ }^{1}$ İzmir Katip Çelebi Üniversitesi, Atatürk Eğitim Ve Araştırma Hastanesi, Medikal Onkoloji Bilim Dalı, İzmir, Türkiye

${ }^{2}$ İzmir Katip Çelebi Üniversitesi, Atatürk Eğitim Ve Araştırma Hastanesi, İç Hastalıkları Anabilim Dalı, İzmir, Türkiye
\end{abstract}

\section{ÖZET}

GÍRİş ve AMAÇ: Bu çalışmada, adelosesan ve genç erişkin (AGE'li) meme kanseri olan hastalarda aspartat aminotransaminazın alanin aminotransaminaza (De-Ritis oranı) oranının prognostic bir belirteç olarak rolü araştırıldı.

YÖNTEM ve GEREÇLER: Bu çalışmada, Ocak 2006 - Mayıs 2016 tarihleri arasında İzmir Katip Çelebi Üniversitesi Atatürk Eğitim ve Araştırma Hastanesi Tıbbi Onkoloji Kliniğinde izlenen 18-39 yaşları arasındaki hastaları geriye dönük olarak değerlendirdi. De-Ritis oranının cut-off değerlerini bulmak için ROC eğrisi analizi kullanılmıştır. Hastalar kesim değerine göre iki gruba ayrıldı.

BULGULAR: Toplamda 190 meme kanseri hastası vardı. Tanı sırasındaki ortanca yaş 34 idi (min: 23, maks: 39). Takiplerinde 37 hastada (\% 19.5) nüks saptand. Histolojik olarak, hastaların büyük çoğunluğu 2. ve 3. derece idi. Tek değişkenli analizde De-Ritis oranının, histolojik derecenin, ER durumunun, PR durumunun ve Luminal durumunun hastalıksız sağkalım(HS) açısından iyi prognostik faktörler olduğunu saptandı [sırasıyla p: 0.014, p: 0.006, p: 0.032, p: 0.002, p: 0.05]. De-Ritis oran1<0,93 olan grupta HS 106,2 ay iken De-Ritis oranı $\geq 0,93$ 79,2 ay olarak saptandı (p: 0,014). Hastalıksız sağklaım açısından çok değişkenli analizde histolojik derece, PR durumu ve De-Ritis oranı istatistiksel olarak anlamlı bulundu.

TARTIŞMA ve SONUÇ: Bu çalışmada De-Ritis oranının adelosesan ve genç erişkin meme kanserli hastalarda prognostik bir belirteç olarak kullanılabileceği gösterilmiştir.

Anahtar Kelimeler: Meme kanseri, AGE, De-Ritis oran1, AST, ALT

\section{ABSTRACT}

INTRODUCTION: The present study aimed to investigate the potential of ratio of aspartate aminotransaminase to alanine aminotransaminase (De-Ritis ratio) as prognostic marker in adelocesant and young adults(AYAs) patients with breast cancer.

METHODS: This study retrospectively evaluated patients aged 18-39 who were followed-up from January 2006 to May 2016 at the Medical Oncology Clinic of Izmir Katip Celebi University, Ataturk Training and Research Hospital. In order to find out De-Ritis ratio cut-off values, ROC curve analysis was used. The patients were divided into two groups according to the cutoff value.

RESULTS: We had 190 patients with breast cancer in total. The median age at diagnosis was 34 (min: 23, max: 39). 37 patients (19.5\%) experienced a relapse in the follow-up period. Histologically, the great majority of patients were grade 2 and 3. The univariate analysis demonstrated that De-Ritis ratio, histological grade, ER status, PR status and Luminal status were good prognostic factors in terms of disease free survival(DFS) [p: 0.014, p: 0.006, p: 0.032, p: 0.002, p: 0.05 respectively]. The group De-Ritis ratio<0,93 had 106.2 months of DFS while the group De-ritis ratio $\geq 0,93$ had 79.2 months $[\mathrm{p}<0.014]$. In multivariate analysis for DFS histological grade, PR status and De-Ritis ratio were found to be statistical significance. 
DISCUSSION AND CONCLUSION: In this study, it has been shown that the De-Ritis ratio can be used as a prognostic marker in AYAs with breast cancer.

Keywords: Breast cancer, AYAs, De-Ritis ratio, AST, ALT

\section{INTRODUCTION}

Adolescents and young adults (AYAs) refer to the individuals aged between 15 and 39 years. Breast cancer is the most prevalent type of cancer among AYAs women ${ }^{[1]}$. Of 200,000 breast cancer cases diagnosed in the US every year, approximately 13,000 (6.6\%) represent women younger than 40 years ${ }^{[2]}$. In a Turkish study conducted on 11,385 breast cancer cases, AYAs rate was found to be $17 \%{ }^{[3]}$.

Compared with other peer groups, the past 25 years saw less progress in terms of increasing survival in AYAs breast cancer cases. The unclarity regarding the biological characteristics of those cancers and inadequate clinical studies are among the reasons for poor outcome observed in this population.

Recent evidence shows that AYAs with breast cancer differs from the aged population in clinical and etiological terms ${ }^{[1]}$. Some studies demonstrated that AYAs with breast cancers were diagnosed at rather advanced stages and characterized with a poorer prognosis, more aggressive phenotype, lower ER positivity, and higher histological grades. Other studies found that it was associated with a higher Her2 expression as well as a larger tumor size, and higher number of lymph node involvement ${ }^{[1,4-}$ 6].

A number of studies were carried out comparing younger and older patients in order to reveal age-related differences in breast cancer. In a study by Alders et al., in which they evaluated 700 breast cancer cases by dividing them into peer groups (younger than 45 and older than 65), they found less ER positivity $(71 \%$ vs. $80 \%$; $\mathrm{p}=0.27)$, a higher rate of Grade 3 ( $56 \%$ vs. $26 \%$; p<0.0001), a higher rate of axillary lymph node metastasis (38\% vs. $25 \% ; \mathrm{p}=0.008)$ and a higher pathological T (>T2; $62 \%$ vs. $47 \% ; \mathrm{p}=0.012)$ [7].

The ratio of the serum levels of aspartate aminotransferase (AST) to alanine aminotransferase (ALT) was first defined by Fernando De-Ritis, and since his description, the AST/ALT ratio has been accepted as DeRitis ratio ${ }^{[8]}$.
AST and ALT are liver enzymes that are very commonly used in various clinical fields. Although AST and ALT are often released from the liver to the blood, they are also released by both malign and non-malign cells; and some studies showed that it has prognostic value for certain types of cancer ${ }^{[9-14]}$.

A study by Bezan et al. demonstrated preoperative increased serum AST/ALT ratio to be an important marker for overall survival (OS) after renal cell carcinoma operation ${ }^{[13]}$. In this context, the reason is considered to be the increased aerobic glycolysis in cancer cells, which is also known as the "Warburg Effect" [15]. As breast cancer may also be associated with an increased glucose metabolism, we hypothesize that the AST/ALT ratio may play a prognostic role in breast cancer ${ }^{[16]}$. To our knowledge, it is not clear whether De-Ritis ratio has a prognostic value for breast cancer. Therefore, we aimed to determine whether DeRitis ratio, which is measured preoperatively in non-metastatic AYAs patients with breast cancer, as well as demographic data and other factors that could be of prognostic significance.

\section{MATERIAL and METHODS}

This study retrospectively evaluated patients aged 18-39 who were followed-up from January 2006 to May 2016 at the Medical Oncology Clinic of Izmir Katip Celebi University, Ataturk Training and Research Hospital. Prior to the study, an approval was received from the university's ethical board. Patients with fully accessible data were included in the study. A total of 910 patients with breast cancer were screened, and patients older than 40 age were excluded from the study. Patients with viral hepatitis, patients receiving neoadjuvant chemotherapy, patients diagnosed with pathological in situ carcinoma, and those with serious comorbidities were also excluded from the study. The patients who were metastatic at diagnosis were excluded for De-Ritis analysis; biochemical results which were one week before surgery were used to proportion AST $(\mathrm{u} / \mathrm{L})$ to $\operatorname{ALT}(\mathrm{u} / \mathrm{L})$ in order to find De-Ritis ratio. Female patients followed-up for at least 24 months were included. All patients' AST and 
ALT values were found through standard clinical test methods.

The following data were also recorded for all patients: age, age at diagnosis, marital status, date of death, last follow-up, comorbidities, smoking status, family history of cancer, tumor location (right or left breast), type and date of operation, date of recurrence, axilla and sentinel lymph node status, tumor type, grade, carcinoma in situ presence, estrogen receptor (ER) and progesterone receptor (PR) status, epidermal growth factor receptor 2 (Her-2), the fraction of $\mathrm{Ki}-67$, presence of metastasis at diagnosis, metastasis during follow-up, location of metastasis if any and adjuvant treatments (chemotherapy, hormone therapy, luteinizing hormone releasing hormone (LHRH) analogue therapy and radiotherapy).

The clinical stage was determined according to the Union for International Cancer Control TNM classification system, 7th edition. The categorization of molecular subtypes was constructed according to the St Gallen International Breast Cancer Conference 2011 [17]: luminal A (ER + and/or PR+, Ki67 low and HER2-), luminal B (ER + and/or PR+, Ki67 high and/or HER2+), HER2-positive (ER-, PRand HER2+) and triple-negative type (ER-, PRand HER2-)

Statistical method

The data were evaluated by using "SPSS 20.0 for Windows" package program. Overall survival (OS) was calculated from the time of diagnosis to death; progression-free survival (DFS) from the date of operation to the detection of first local and/or distant recurrence or the date on which the patient was seen for the last time (for patients who did not appear for follow-up). The efficacy of using the AST/ALT ratio (De-Ritis ratio) to predict DFS was analyzed using the receiver operating characteristic (ROC) curve. The patients were divided into two groups according to the cutoff value. Mann-Whitney $U$ Test was used to compare the ratio between groups, the 'KaplanMeier method' was employed for survival analyses, and the groups' survival values were compared using the log-rank test. The prognostic significance of certain factors was assessed using the Cox proportional hazards regression model. $\mathrm{P}<0.05$ was taken to indicate statistical significance.

\section{RESULTS}

We had 190 patients with breast cancer in total. The median age at diagnosis was 34 (min:23, max:39). We found 138 ER-positive (72.6\%), 137 PR-positive (72.1\%), and 52 Her-2 positive $(27.4 \%)$ in pathological examination of these patients. Histologically, the great majority of patients were grade 2 and 3 . The median tumor diameter was $3.30 \mathrm{~cm}$ (min: $0.4 \mathrm{~cm}$, max: 12 $\mathrm{cm})$. Regarding the stage at diagnosis; 35 patients $(18.4 \%)$ were stage I, 90 patients (47.4\%) were stage II, 40 patients $(21.1 \%)$ were stage III, and 25 patients (13.2\%) were stage IV.

Table 1. Demographic characteristics of patients with AYA breast cancer

\begin{tabular}{|c|c|}
\hline Characteristics & $\begin{array}{l}\text { Number of Patients } \\
\text { (percentage) }\end{array}$ \\
\hline Age, year (mean) & $33.54(23-39)$ \\
\hline \multicolumn{2}{|l|}{ Marital Status } \\
\hline Married & $167(87.8 \%)$ \\
\hline Single & $23(12.1 \%)$ \\
\hline \multicolumn{2}{|l|}{ Smoking } \\
\hline Smoker & $13(6.8 \%)$ \\
\hline Non-smoker & $177(93.2 \%)$ \\
\hline \multicolumn{2}{|l|}{ Comorbidity } \\
\hline Yes & $16(8.4 \%)$ \\
\hline No & $174(81.6 \%)$ \\
\hline \multicolumn{2}{|c|}{ Family History of Breast Cancer } \\
\hline Yes & $11(5.8 \%)$ \\
\hline No & $179(94.2 \%)$ \\
\hline \multicolumn{2}{|l|}{ Tumor Localization } \\
\hline Left Breast & $102(53.7 \%)$ \\
\hline Right Breast & $86(45.3 \%)$ \\
\hline Bilateral & $2(1.1 \%)$ \\
\hline \multicolumn{2}{|l|}{ Type of Tumor } \\
\hline Invasive Ductal Carcinoma & $137(72.1 \%)$ \\
\hline Invasive Medullar Carcinoma & $4(2.1 \%)$ \\
\hline Invasive Lobular Carcinoma & $10(5.1 \%)$ \\
\hline Mixed Type & $22(11.6 \%)$ \\
\hline Other & $17(8.9 \%)$ \\
\hline \multicolumn{2}{|l|}{ Carcinoma In Situ Presence } \\
\hline Yes & $105(55.3 \%)$ \\
\hline No & $85(44.7 \%)$ \\
\hline \multicolumn{2}{|l|}{ ER Status } \\
\hline Positive & $138(72.6 \%)$ \\
\hline Negative & $52(27.4 \%)$ \\
\hline \multicolumn{2}{|l|}{ PR Status } \\
\hline Positive & $137(72.1 \%)$ \\
\hline Negative & $53(27.9 \%)$ \\
\hline \multicolumn{2}{|l|}{ Her-2 Status } \\
\hline Positive & $52(27.4 \%)$ \\
\hline Negative & $138(72.6 \%)$ \\
\hline \multicolumn{2}{|l|}{ Histological Grade } \\
\hline Grade 1 & $10(5.3 \%)$ \\
\hline Grade 2 & $101(53.2 \%)$ \\
\hline Grade 3 & $79(41.6 \%)$ \\
\hline \multicolumn{2}{|l|}{ Stage at Diagnosis } \\
\hline Stage 1 & $35(18.4 \%)$ \\
\hline Stage 2 & $90(47.4 \%)$ \\
\hline Stage 3 & $40(21.1 \%)$ \\
\hline Stage 4 & $25(13.2 \%)$ \\
\hline
\end{tabular}




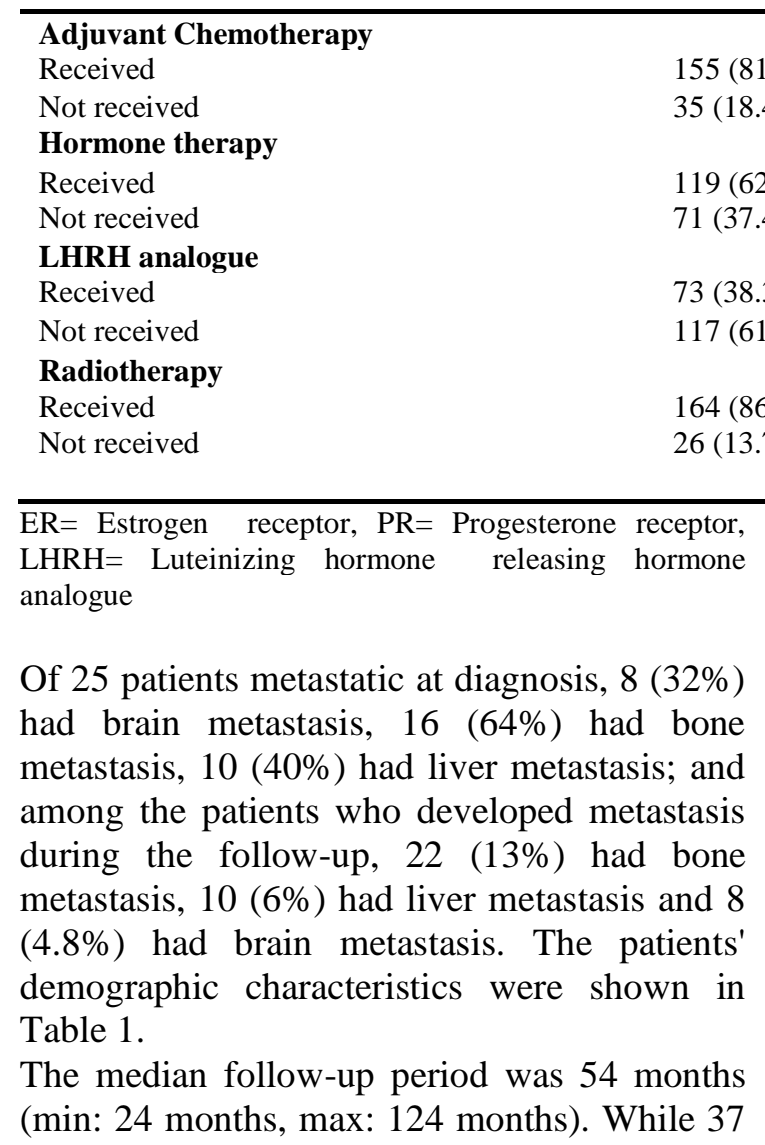

patients $(19.5 \%)$ had a recurrence during the $155(81.6 \%) \quad$ follow-up, $35(18.4 \%)$ patients were dead. In a $35(18.4 \%)$ total of 165 patients in the adjuvant setting $19(62.6 \%)$ (excluding 25 patients metastatic at diagnosis), $71(37.4 \%)$ the cutoff value for the De-Ritis ratio was set at 0.93 according to the Roc curve (p:0.028) $73(38.3 \%) \quad$ (Figure 1); therefore eighteen patients (16.5\%) $117(61.6 \%)$ presenting De-Ritis ratios less than 0.93 (n: 109 $64(86.3 \%)$ patients) had a recurrence, and 19 patients $26(13.7 \%) \quad(33.9 \%, \mathrm{n}: 56)$ with De-Ritis ratio equal to or higher than 0.93 developed a recurrence (p:0.014). In those patients with De-Ritis ratios less than 0.93, 3-year disease-free survival (DFS) rate was $86 \%$, and 5-year DFS was $75 \%$; however, those rates were $73 \%$ and $56 \%$, respectively, for those patients with De-Ritis ratios less than 0.93 (p:0.014) (Figure 2). The univariate analysis demonstrated that De-Ritis ratio, histological grade, ER status, PR status and Luminal status were good prognostic factors in terms of DFS (p:0.014, p:0.006, p:0.032, p:0.002, p:0.05 respectively). A univariate analyses of various parameters as predictors of DFS in 165 patients with AYAs with breast cancer were shown in Table 2 .

Table 2. Univariate analyses of various parameters as predictors of disease free survival in 165 patients with AYA with breast cancer.

\begin{tabular}{|c|c|c|}
\hline Variables & $\begin{array}{l}\mathrm{N} \text { (number of patients with disease } \\
\text { recurrence) }\end{array}$ & $\begin{array}{l}\text { Univariate analysis } \\
P \text { value }\end{array}$ \\
\hline De Ritis ratio $(<0.93$ vs $\geq 0.93)$ & 109(18) vs 56(19) & 0.014 \\
\hline Histological grade $(1,2,3)$ & $10(0)$ vs $88(14)$ vs $67(23)$ & 0.006 \\
\hline ER status (neg vs. pos) & $43(16)$ vs $122(21)$ & 0.032 \\
\hline PR status (neg vs. pos) & $43(17)$ vs $122(20)$ & 0.002 \\
\hline $\begin{array}{l}\text { Luminal status (Lum A, Lum B, Her2 } \\
\text { overexpression, basal-like) }\end{array}$ & $69(7)$ vs $58(16)$ vs $11(4)$ vs $27(10)$ & 0.05 \\
\hline Concomitant CIS (neg. vs. pos.) & $66(19)$ vs $99(18)$ & 0.436 \\
\hline Adjuvant chemotherapy (neg vs. pos.) & $22(4)$ vs $143(33)$ & 0.826 \\
\hline Adjuvant radiotherapy (neg vs. pos) & $21(6)$ vs $144(31)$ & 0.555 \\
\hline $\begin{array}{l}\text { Her-2 status (neg. vs. pos.) } \\
\text { Marital status (single vs married) }\end{array}$ & $\begin{array}{l}124(27) \text { vs } 41(10) \\
21(6) \text { vs } 144(31)\end{array}$ & $\begin{array}{l}0.996 \\
0.821\end{array}$ \\
\hline Reception of LHRH analog (neg. vs. pos.) & $99(24)$ vs $66(13)$ & 0.765 \\
\hline Family history of cancer (neg vs. pos) & $156(33)$ vs $9(4)$ & 0.207 \\
\hline Stage $(1,2,3)$ & $35(4)$ vs $90(20)$ vs $40(13)$ & 0.139 \\
\hline
\end{tabular}

ER= estrogen receptor, $\mathrm{PR}=$ progesterone receptor, $\mathrm{CIS}=$ carcinoma in situ, Lum= Luminal, Neg= negative, Pos= positive 
A univariate overall survival analysis according to tumor histological grade, grade 3 patients revealed a shorter survival time (p:0.027). Likewise, when those patients who were metastatic at diagnosis were excluded (n: 165), $16(37.2 \%)$ of 43 ER-negative patients and 21 of $122(17.2 \%)$ ER-positive patients presented a recurrence (p:0.05). Similarly, $17(39.5 \%)$ of 43 PR-negative patients and $20(16.4 \%)$ of 122 PR-positive patients had a recurrence (p:0.003). A total of 165 patients non-metastatic at diagnosis were categorized into Luminal A (41.8\%, n:69), Luminal B (9.5\%, n:58), Her-2 overexpression $(6.6 \%, \mathrm{n}: 11)$ and Basallike(16.3\%, n: 27) molecular subtypes. Their overall survival analysis revealed that Luminal A presented a better prognosis, while basal-like category had a poorer prognosis (p:0.006). 5year and 10-year OS rates were evaluated according to patients' molecular subtype of breast cancer. The 5-year and 10-year OS rates were as follows, respectively: $94 \%$ and $62 \%$ for Luminal A, 75\% and $49 \%$ for Luminal B, $61 \%$ and $0 \%$ for Her-2 expression, and $71 \%$ and $39 \%$ for the Basal-like subtype (p:0.006) (Table 3). An analysis of survival by tumor stage produced the following results for estimated survival time: 120 months for stage I, 115 months for stage II, 93 months for stage III and 36 months for stage IV.

In multivariate analysis for DFS histological grade, PR status and De-Ritis ratio were found to be significant (Table 4). Another multivariate analysis showed that only PR status were significant in terms of OS (Relative risk:11.8, p:0.001).

Table 3. Univariate analyses of various parameters as predictors of overall survival in 165 patients with AYA with breast cancer.

\begin{tabular}{|c|c|c|}
\hline Variables & $\begin{array}{l}\mathrm{N}, \text { (Number of patients with disease } \\
\text { recurrence) }\end{array}$ & $\begin{array}{l}\text { Univariate analysis } \\
\text { p value }\end{array}$ \\
\hline De Ritis ratio $(<0.93$ vs $\geq 0.93)$ & $109(12)$ vs $56(11)$ & 0.278 \\
\hline Histological grade $(1,2,3)$ & $10(0)$ vs $88(9)$ vs $67(14)$ & 0.027 \\
\hline Concomitant CIS (neg. vs. pos.) & $66(10)$ vs $99(13)$ & 0.451 \\
\hline Adjuvant chemotherapy (neg vs. pos.) & $22(3)$ vs $143(20)$ & 0.989 \\
\hline ER status (neg vs. pos) & $43(11)$ vs $122(12)$ & 0.05 \\
\hline PR status (neg vs. pos) & $43(13)$ vs $122(10)$ & 0.002 \\
\hline Adjuvant radiotherapy (neg vs. pos) & $21(4)$ vs $144(18)$ & 0.583 \\
\hline Her-2 status (neg. vs. pos.) & $124(17)$ vs $41(6)$ & 0.992 \\
\hline Marital status (single vs married) & $21(3)$ vs $144(20)$ & 0.477 \\
\hline Reception of LHRH analog (neg. vs. pos.) & $99(17)$ vs $66(6)$ & 0.273 \\
\hline Family history of cancer(neg vs. pos) & $156(22)$ vs $9(1)$ & 0.828 \\
\hline $\begin{array}{l}\text { Luminal status (Lum A, Lum B, Her2 } \\
\text { overexpression, basal-like) }\end{array}$ & $69(1)$ vs $58(11)$ vs $11(2)$ vs $27(9)$ & 0.006 \\
\hline Stage $(1,2,3)$ & $35(1)$ vs $90(11)$ vs $40(11)$ & 0.056 \\
\hline
\end{tabular}

ER: estrogen receptor, PR=progesterone receptor, CIS=carcinoma in situ, Lum=Luminal, Neg= negative , Pos= positive,

Table 4. Multivariate analyses of various parameters as predictors of disease free survival in 165 patients with AYA with breast cancer.

\begin{tabular}{llcc}
\hline Variable & Relative Risk & 95 \% Confidence Interval & P value \\
\hline De-Ritis Ratio & 5.19 & $0.243-0.894$ & 0.023 \\
Histological Grade & 4.86 & $1.069-4253$ & 0.027 \\
\hline
\end{tabular}

Adress for correspondence: İzmir Katip Çelebi Üniversitesi Atatürk Eğitim Ve Araştırma Hastanesi Tıbbi Onkoloji Polkiniği Yeşilyurt /izmir 35330 İzmir - Türkiye e-mail: u.oflaz@mynet.com

Available at www.actaoncologicaturcica.com

Copyright $\odot$ Ankara Onkoloji Hastanesi 


\begin{tabular}{lccc}
\hline PR Status & 4.28 & $0.241-0.955$ & 0.038 \\
\hline PR= Progesterone receptor & & \\
\hline
\end{tabular}

$\mathrm{PR}=$ Progesterone receptor

Figure 1. Receiver operating characteristic analysis of De-Ritis ratio. Receiver operating characteristic analysis of 165 patients with AYAs breast cancer. The area under the curve (AUC) for the preoperative De-Ritis ratio was 0.93

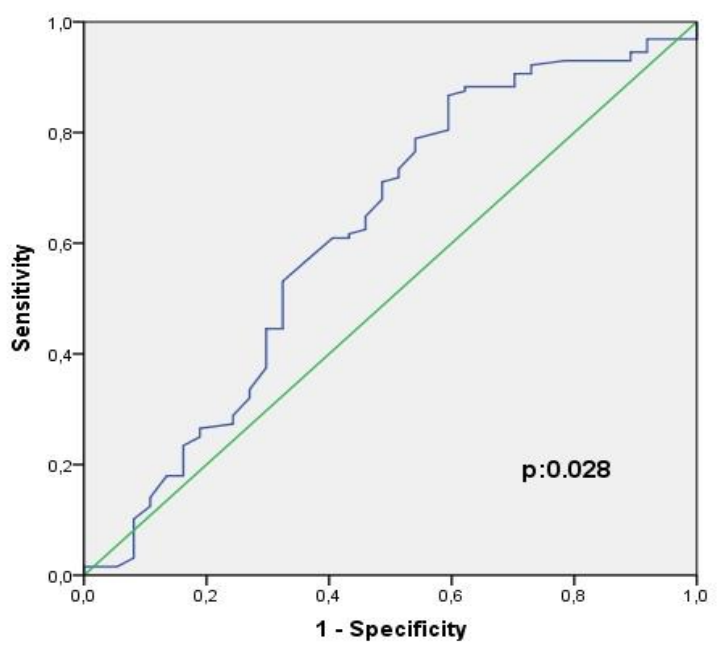

Figure 2. Kaplan-Meier analysis of disease-free survival according to preoperative De-Ritis ratio (AST/ALT ratio) among 165 patients with AYAs breast cancer.

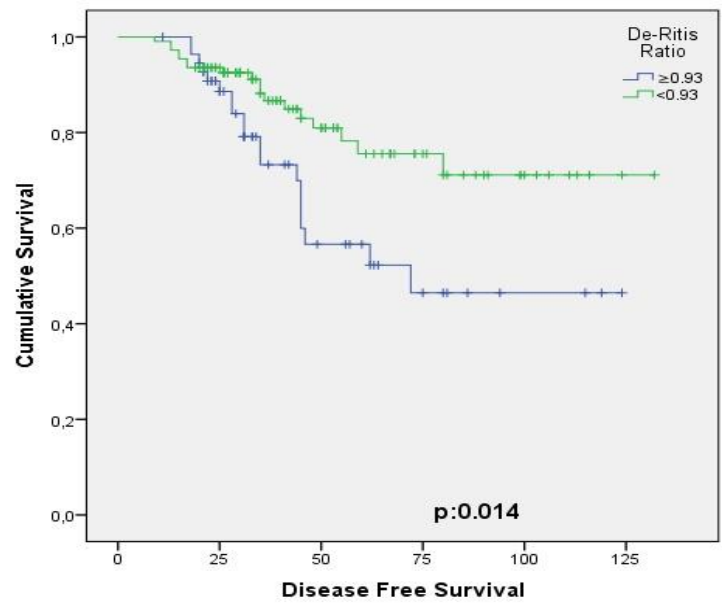

\section{DISCUSSION}

Young age is a negative prognostic factor for breast cancer. Those young women usually refer at a more advanced stage and present a more aggressive disease. An evaluation of the histological subgroups of patients indicated the most frequent histological subtype to be invasive ductal carcinoma (72.1\%). In a study by Ozmen, who evaluated a total of 11,385 Turkish patients with breast cancer, the most frequent histological subtype was ductal carcinoma (79\%). The same study found the ratio of stage $0-1-2$ as $71.5 \%$, stage 3 as $19 \%$, and stage 4 as $5 \%$ in the group of patients aged $<40$; these ratios were found $65.8 \%$ for stage 1 $2,21.1 \%$ for stage 3 and $13.2 \%$ for stage 4 in our study. In Ozmen's study, ER, PR and HER2 positivity rates were $61 \%, 57 \%$ and $26.5 \%$, respectively. In our study, however, those rates were found to be $72.6 \%, 71.2 \%$, and $27.4 \%$, respectively. While Luminal A, Luminal B, Her2 overexpression and basal-like rates were $39.5 \%, 35.8 \%, 8.4 \%$ and 16.3 , respectively, these rates were found by Ozmen to be $56 \%$, $19 \%, 8 \%$, and $17 \%$, respectively. Although the ratio of histological grade 3 patients was $41.6 \%$ in our study, Ozmen found it at such a high rate at $60 \%$. In our study, the ratio of patients without an axillary lymph node metastasis was $44.7 \%$, which was found to be $44 \%$ by Ozmen ${ }^{[3]}$. The findings of this study are in line with Ozmen's study. The similarity of both findings suggests that they are consistent for the Turkish society ${ }^{[3]}$.

In general, various factors, such as patient features (age ${ }^{[18]}$ and race), pathologic factors (including tumor size ${ }^{[19]}$, nodal involvement ${ }^{[20]}$, tumor morphology [21], histologic grade ${ }^{[22]}$, peritumoral lymphovascular invasion ${ }^{[23]}$ ), tissue markers (such as hormone receptors ${ }^{[24]}$, HER2 overexpression $^{[25]}$ ), genomic profiles (luminal subtypes ${ }^{[26]}$ ), markers of proliferation (such as Ki-67 ${ }^{[27]}$, urokinase plasminogen activator system $^{[28]}$ ) affect the prognosis of breast cancer. In our study, the univariate analysis demonstrated that De-Ritis ratio, histological grade, ER status, PR status and Luminal status 
were good prognostic factors in terms of disease free survival. Also in our multivariate analysis of histological grade, PR status and De-Ritis ratio, they were found significant in terms of disease-free survival. Although previous studies did not investigate the prognostic importance of De-Ritis ratio in breast cancer, its prognostic importance was assessed and demonstrated for other types of cancer including head and neck cancer, renal cell cancers, urothelial cancers, cholangiocarcinoma, etc. ${ }^{[9,12,14,29]}$. In our study, the cutoff value for De-Ritis ratio was determined to be 0.93 based on the ROC curve analysis. In the low-De-Ritis-ratio group, 3-year DFS was 86\%, 5-year DFS was 75\% and 8-year DFS was $71 \%$, while those rates were found in the high-De-Ritis-ratio group to be $73 \%, 56 \%$ and $46 \%$, respectively (p:0.014).

Lee et al. evaluated a total of 623 patients who underwent nephroureterectomy due to urothelial cancer and found that preoperative De-Ritis ratio indicated worse progression free survival (PFS), shorter cancer-specific survival, as well as shorter overall survival $(p<0.001)$. The same study also revealed through a multivariate analysis that a high De-Ritis ratio was an independent predictive factor for PFS, cancer-specific survival and overall survival (all $\mathrm{p}<0.001)^{[9]}$. In another study that included a total of 149 operated patients with renal cell cancer, a high De-Ritis ratio was found to be associated with a lower disease-specific survival and overall survival $(\mathrm{p}<0.001)^{[30]}$. In our study, De-Ritis ratio was not found significant in terms of overall survival. The reason of this may be due to different salvage treatments received by patients which might have affected the survival outcome of our patients.

Changes in cell metabolism are considered to be a major characteristic of cancer. Warburg effect is the metabolic phenotype that best characterizes the aerobic glycolysis observed in tumor cells. Warburg effect is also the most famous cancer metabolism that identifies increased abnormal aerobic glycolysis in cancer cells for ATP production, even under sufficient oxygen conditions ${ }^{[15,31]}$. This increased glycolysis is known to depend on a series of changes in NADH-related enzymes and mitochondrial activities related to glucose carriers ${ }^{[32]}$. Warburg further assumed that cancer cells presented a mitochondrial dysfunction ${ }^{[15,31]}$. Recent studies demonstrated that proliferating cancer cells show aerobic glycolysis as well as increased glutamine metabolism to maintain nucleotide biosynthesis and nonessential amino acids, which are catalyzed by AST and ALT ${ }^{[33-36]}$. Increased glutamine catabolism is more developed in cancer cells in order to support the metabolites of the tricarboxylic acid cycle [31]. Catalyzing the transformation of pyruvate and glutamate to alanine and alpha-ketoglutarate, ALT functions in both glycolysis and glutaminolysis [37]. Therefore, compared with serum AST levels, increased metabolism in aggressive cancer cells result in ALT consumption and thus lower ALT levels, which, in turn, increases De-Ritis ratio [38]. The hypothesis above is the one that is most likely to account for the change in AST/ALT ratio. In a study conducted by O'Reilly et al. on the prognostic factors in breast cancer patients with liver metastasis, increased AST level is demonstrated to be a prognostic factor, which may be related to the hypothesis above ${ }^{[10]}$. Similarly, in a study that investigated prognostic factors in patients with advancedstage pancreatic cancer, increased serum AST level was found to be associated with poor prognosis ${ }^{[11]}$.

Our study is a retrospective study with limited number of patients. Another limitation of this study is that although the patients with any comorbidity that may affect transaminase levels were excluded, it may not have been possible to exclude each one of them (due to drug use, fatty liver, etc.).

\section{CONCLUSION}

In conclusion, AYAs patients with breast cancer present more aggressive tumors with higher histological grades, their HER2 positivity rate is higher than the older group, and they rather refer with stage 3 and stage 4 tumors at diagnosis. This study demonstrates that DeRitis ratio could be used as a prognostic marker in the adolescents and young adult peer group with breast cancer. However, this must be verified through further prospective studies with larger patient populations.

\section{Acknowledgment: None}

Author contributions: Utku Oflazoglu participated in study design, statistics and 
coordination and helped to interpret the data and wrote the manuscript. Yuksel Kucukzeybek, Umut Varol, and Ahmet Alacacioglu participated in data analysis and interpretation, statistics and revised the manuscript critically. Yakup Iriagac, Tarik Salman, Halil Taskyanatan, Yasar Yildiz, participated in the study design and oriented the data collection. All authors read and approved the final manuscript.

Funding: None

Conflict of Interest: The authors declare no conflicts of interest

\section{REFERENCES}

1. Bleyer A, Barr R, Hayes-Lattin B, Thomas D, Ellis C, Anderson B: The distinctive biology of cancer in adolescents and young adults. Nat Rev Cancer (2008), 8:288-298,

2. Anders, C. K., Johnson, R., Litton, J., Phillips, M. \& Bleyer, A. Breast Cancer Before Age 40 Years. Semin. Oncol. (2009) 36(3), 237-249.

3. Ozmen V. Breast Cancer in Turkey: Clinical and Histopathological Characteristics (Analysis of 13.240 Patients) J Breast Health (2014), Apr; 10(2): 98-105.

4. Gabriel, C. a \& Domchek, S. M. Breast cancer in young women. Breast Cancer Res (2010). 12(5):212.

5. Gnerlich, J. L., Deshpande, A. D., Jeffe, D. B., Sweet, A., White, N., \& Margenthaler, J. A. Elevated Breast Cancer Mortality in Women Younger than Age 40 Years Compared with Older Women Is Attributed to Poorer Survival in Early-Stage Disease. J. Am. Coll. Surg. (2009) 208(3), 341-347.

6. Anders C. K., Hsu S. D., Acharya C. R., Zhang Y., Wang Y., Foekens J. A. et al. Molecular signatures characterize early stage breast cancer arising in young women and have prognostic and therapeutic implications independent of ER status. J. Clin. Oncol. (2007), 25, 522. 7. Anders, C. K., Hsu, D. S., Broadwater, G., Acharya, C. R., Foekens, J. A., Zhang, Y. et al. Young age at diagnosis correlates with worse prognosis and defines a subset of breast cancers with shared patterns of gene expression. $J$. Clin. Oncol. (2008), 26(20), 3324-3330.

8. De Ritis, F., Giusti, G. \& Coltorti, M. Serum phosphoglucomutase activity in human virus hepatitis. Experientia (1957),13, 81-82

9. Lee, H., Choi, Y. H., Sung, H. H., Han, D. H., Jeon, H. G., Chang Jeong, B et al. De Ritis Ratio (AST/ALT) as a Significant Prognostic Factor in Patients With Upper Tract Urothelial Cancer Treated With Surgery. Clin. Genitourin. Cancer (2018), 15, 379-385

10. O'Reilly, S. M., Richards, M. A. \& Rubens, R. D. Liver metastases from breast cancer: the relationship between clinical, biochemical and pathological features and survival. Eur. J. Cancer Clin. Oncol. (1990), 26, 574577.

11. Stocken, D. D., Hassan, A. B., Altman, D. G., Billingham, L. J., Bramhall, S. R., Johnson, P. J., et al. Modelling prognostic factors in advanced pancreatic cancer. Br. J. Cancer (2008), 99, 883

12. Takenaka, Y., Takemoto, N., Yasui, T., Yamamoto, Y., Uno, A., Miyabe, H., et al. Transaminase activity

Adress for correspondence: İzmir Katip Çelebi Üniversitesi Atatürk Eğitim Ve Araştırma Hastanesi Tibbi Onkoloji Polkiniği Yeşilyurt/izmir 35330 İzmir - Türkiye e-mail: u.oflaz@mynet.com

Available at www.actaoncologicaturcica.com

Copyright $($ Ankara Onkoloji Hastanesi

predicts survival in patients with head and neck cancer. PLoS One 1 (2016),11(10), e0164057

13. Bezan, A., Mrsic, E., Krieger, D., Stojakovic, T., Pummer, K., Zigeuner, R., et al. The preoperative AST/ALT (De Ritis) ratio represents a poor prognostic factor in a cohort of patients with nonmetastatic renal cell carcinoma. J. Urol. (2015), 194, 30-35

14. Tan X., Xiao K., Liu W., Chang S., Zhang T., Tang H. Prognostic factors of distal cholangiocarcinoma after curative surgery: a series of 84 cases. Hepatogastroenterology. (2013), 60, 1892-1895

15. WARBURG O. On the origin of cancer cells. Science; (1956), 123: 309-314

16. Hou, Y., Zhou, M., Xie, J., Chao, P., Feng, Q., \& Wu, $\mathrm{J}$. High glucose levels promote the proliferation of breast cancer cells through GTPases. Breast Cancer (London). (2017), 9, 429-436.

17. Goldhirsch A, Wood W.C., Coates A.S., Gelber R.D., Thurlimann B, Senn H.J. Strategies for subtypes-dealing with the diversity of breast cancer: highlights of the St. Gallen International Expert Consensus on the Primary Therapy of Early Breast Cancer 2011. Ann Oncol, (2011), 22(8):1736-1747.

18. Adami HO, Malker B, Holmberg L, et al. The relation between survival and age at diagnosis in breast cancer. $N$ Engl J Med (1986); 315:559.

19. Fisher B, Slack NH, Bross ID. Cancer of the breast: size of neoplasm and prognosis. Cancer (1969); 24:1071. 20. Siegel RL, Miller KD, Jemal A. Cancer Statistics, 2017. CA Cancer J Clin (2017); 67:7.

21. Pestalozzi BC, Zahrieh D, Mallon E, et al. Distinct clinical and prognostic features of infiltrating lobular carcinoma of the breast: combined results of 15 International Breast Cancer Study Group clinical trials. $J$ Clin Oncol (2008); 26:3006.

22. Elston CW, Ellis IO. Pathological prognostic factors in breast cancer. I. The value of histological grade in breast cancer: experience from a large study with long-term follow-up. Histopathology (1991); 19:403.

23. Pinder SE, Ellis IO, Galea M, et al. Pathological prognostic factors in breast cancer. III. Vascular invasion: relationship with recurrence and survival in a large study with long-term follow-up. Histopathology (1994); 24:41. 24. Harvey JM, Clark GM, Osborne CK, Allred DC. Estrogen receptor status by immunohistochemistry is superior to the ligand-binding assay for predicting response to adjuvant endocrine therapy in breast cancer. $J$ Clin Oncol (1999); 17:1474.

25. Tandon AK, Clark GM, Chamness GC, et al. HER$2 /$ neu oncogene protein and prognosis in breast cancer. $J$ Clin Oncol (1989); 7:1120.

26. Sørlie T, Perou CM, Tibshirani R, et al. Gene expression patterns of breast carcinomas distinguish tumor subclasses with clinical implications. Proc Natl Acad Sci U S A (2001); 98:10869.

27. de Azambuja E, Cardoso F, de Castro G Jr, et al. Ki67 as prognostic marker in early breast cancer: a metaanalysis of published studies involving 12,155 patients. $\mathrm{Br}$ J Cancer (2007); 96:1504.

28. Malmström P, Bendahl PO, Boiesen P, et al. S-phase fraction and urokinase plasminogen activator are better markers for distant recurrences than Nottingham Prognostic Index and histologic grade in a prospective study of premenopausal lymph node-negative breast cancer. J Clin Oncol (2001); 19:2010. 
29. Canat L, Ataly H.A., Agalarov S., Alkan I., Altunrende F. The effect of AST/ALT (De Ritis) ratio on survival and its relation to tumor histopathological variables in patients with localized renal cell carcinoma. Int Braz J Urol. (2018), 4(2):288-295

30. Gorgel S.N., Kose O, Koc E.M., Ates E., Akin Y., Yilmaz Y. The prognostic significance of preoperatively assessed AST/ALT (De Ritis) ratio on survival in patients underwent radical cystectomy. Int Urol Nephrol. (2017), 49(9):1577-1583.

31. Koppenol W.H., Bounds P.L., Dang C.V. Otto Warburg's contributions to current concepts of cancer metabolism. Nat Rev Cancer ; (2011), 11: 325-337.

32. Dorward A., Sweet S., Moorehead R., Singh G. Mitochondrial contributions to cancer cell physiology: redox balance, cell cycle, and drug resistance. J Bioenerg Biomembr: (1997), 29: 348 385-92.

33. Vander Heiden M.G., Cantley L.C. and Thompson C.B. Understanding the Warburg effect: the metabolic requirements of cell proliferation. Science; (2009), 324: 1029 .
34. Yang, C., Sudderth, J., Dang, T., Bachoo, R. M., McDonald, J. G., \& DeBerardinis, R. J. Glioblastoma cells require glutamate dehydrogenase to survive impairments of glucose metabolism or Akt signaling. Cancer Res; (2009), 69: 7986.

35. Elf SE and Chen J: Targeting glucose metabolism in patients with cancer. Cancer; (2014), 120: 774.

36. Cairns R.A., Harris I.S. and Mak T.W. Regulation of cancer cell metabolism. Nat Rev Cancer; (2011),11: 85.

37. Botros M., Sikaris K.A. The de ritis ratio: the test of time. Clin Biochem Rev; (2013),34: 117-130.

38. Conde V.R., Oliveira P.F., Nunes A.R., Rocha C.S., Ramalhosa E., Pereira J.A., et al. The progression from a lower to a higher invasive stage of bladder cancer is associated with severe alterations in glucose and pyruvate metabolism. Exp Cell Res; (2015), 335: 91-98. 